\title{
PROTECTIVE ACTION OF N-STEAROYLETHANOLAMINE ON BLOOD COAGULATION AND ARTERIAL CHANGES IN SPONTANEOUSLY HYPERTENSIVE RATS FED CHOLESTEROL-RICH DIET
}

\author{
O. S. TKACHENKO', Ie. A. HUDZ ${ }^{1 凶}, H$. V. KOSIAKOVA, \\ P. P. KLYMENKO ${ }^{2}$, Y. M. STOHNII ${ }^{1}$, V. A. DIDKIVSKYI', \\ T. M. CHERNYSHENKO', V. O. CHERNYSHENKO ${ }^{1}$, T. M. PLATONOVA ${ }^{1}$ \\ ${ }^{1}$ Palladin Institute of Biochemistry, National Academy of Sciences of Ukraine, Kyiv; \\ ${ }^{2} S I$ "D. F. Chebotarev Institute of Gerontology of the National Academy \\ of Medical Sciences of Ukraine", Kyiv; \\ 凶e-mail:goudziegor@gmail.com
}

Received: 24 December 2019; Accepted: 27 March 2020

In this work we aimed to test the atherosclerotic changes in the aortic wall and pro-coagulant response of the blood coagulation system of spontaneously hypertensive rats (SHR) fed cholesterol-rich diet (CRD) and to study the effect of the anti-inflammatory agent $N$-stearoylethanolamine (NSE) on the development of atherosclerosis in this model. Female rats $(n=30)$ with genetically determined hypertension proven by direct measurement of blood pressure were fed CRD (5\% cholesterol) for 2 months. Control group of SHR $(n=10)$ received standard pellet diet, 10 were fed CRD and 10 received CRD with daily per os application of NSE at a dose of $50 \mathrm{mg} / \mathrm{kg}$ of body weight. Histological analysis detected swelling and detachment of endothelial cells, huge edema of the subendothelial layer and a disruption of the middle shell integrity. CRD rats had higher fibrinogen concentration, increased rate of platelet aggregation and decreased level of anticoagulant PC. Platelet aggregation speed increased in CRD-fed rats $(52.5 \pm 4.1 \% / \mathrm{min})$ was slightly normalized under the action of NSE ( $40 \pm 8.3$ vs $35 \pm 9 \% / \mathrm{min}$ in controls). Fibrinogen concentration was slightly increased in CRDfed rats (2.75 \pm 0.7 vs $1.9 \pm 0.5 \mathrm{mg} / \mathrm{ml}$ in controls). However, the level of anticoagulant PC that was decreased in CRD-fed rats ( $65 \pm 16$ vs $100 \pm 11 \%$ in controls) was normalized under the action of NSE (92 $\pm 17 \%)$. NSE also influenced the aorta architecture, however normalizing the thickness of the aorticwall did not change the cholesterol-induced inclusions within aorta media. NSE anti-inflammatory action changes the atherogenic processes in CRD-fed rats mainly protecting PC from consumption during the inflammatory process and reducing edema of the aorta. However hematological parameters (including clotting time in the APTT test and fibrinogen concentration) changed independently on NSE application. Anti-aggregatory action of NSE on platelets can be a result of direct action on platelets or the consequence of its anti-inflammatory action. During atherogenesis induced by CRD in the model, NSE demonstrated valuable anti-inflammatory action protecting the organism during atherogenesis, however it cannot be assumed as an antithrombotic or antiatherogenic agent because it is unable to influence hemostasis directly.

K e y w o rd s: atherosclerosis, cholesterol-rich diet, $N$-stearoylethanolamine (NSE), hemostasis.

\section{Introduction}

Development of atherosclerotic plaques is a complex process that leads to lesions in the arterial wall causing both thrombotic complications or haemorrhages. One of the crucial points in this process is inflammation [1]. For instance, atherosclerosis is accompanied by such processes related to inflammation as fibrosis of the intima, formation offatty plaques, proliferation of smooth muscle cells, and migration of immune cells and platelets [2].

(C) 2020 Tkachenko O. S. et al. This is an open-access article distributed under the terms of the Creative Commons Attribution License, which permits unrestricted use, distribution, and reproduction in any medium, provided the original author and source are credited. 
Being a complex disease, atherosclerosis is hard to reproduce in the laboratory and numerous animal models for atherosclerosis can show contradictory results [3].

The main approach for inducing atherosclerosis is a high lipid diet in rabbits [4]. Among other available models, scientists use pigs, non-human primates and genetically modified mice [5]. As for rats, they normally are resistant to atherosclerosis except for spontaneously hypertensive rats (SHR) that have genetically high blood pressure. High blood pressure induces a predisposition to fibromuscular sclerosis that consist of intimal thickening and muscle cell migration from the media. Hypercholesterolemia can cause the propagation of vascular dysfunction and accumulation of lipids in the intracellular matrix of the intima [6].

Some authors found no atherogenic effect of hypercholesterolemia on SHR [7]. Others succeeded but focused mainly on lipid metabolism or homeostasis of cells in vessels, and did not take into account blood coagulation parameters [8-10]. At the same time, recent works demonstrate that inhibition of blood coagulation prevents the development of atherosclerosis [11, 12].

$\mathrm{N}$-stearoylethanolamine (NSE) is a naturally occurring saturated $\mathrm{N}$-acyletanolamine which possesses anti-inflammatory, hypoglycemic and antitoxic properties. Previous studies showed that NSE had membranotropic action andcould influence the cholesterol level and balance between saturated and unsaturated fatty acids [13-15]. Numerous anti-inflamatory effects of NSE make it a prospective agent for the development of anti-inflammatory medicines.

In this work we aimed to test the atherosclerotic changes in the aorta wall and pro-coagulant response of the blood coagulation system of SHR fed a cholesterol-rich diet (CRD). Also, we studied the effect of the anti-inflammatory agent NSE on the development of atherosclerosis in this rat model.

\section{Materials and Methods}

Blood sampling. Samples of rat blood were collected by heart puncture. 3.8\% sodium citrate was added to the blood immediately after collection. Platelet-rich plasma (PRP) was prepared from citrated blood by centrifugation at $1000 \mathrm{rpm}$ for 30 min. Platelet poor plasma (PPP) was obtained from PRP by centrifugation of PRP for $15 \mathrm{~min}$ at $1500 \mathrm{rpm}$.

Reagents. Chromogenic substrates S2238 (HD-Phe-Pip-Arg-pNA), and S2236 (p-Glu-Pro-Arg-
pNa) were purchased from BIOPHEN (Neuvillesur-Oise, France). APTT-reagent and protein C (PC) activator were purchased from Renam (Moscow, Russia). ADP was purchased from Sigma-Aldrich (St. Louis, USA).

Animal model. The model of atherosclerosis was based on CRD SHR. Female SHR $(n=30)$ had genetically determined hypertension proven by direct measurement of blood pressure. Average systolic pressure was $170 \mathrm{~mm} \mathrm{Hg}$ and diastolic pressure was 120-130 mm Hg. Wistar female rats of the same age and weight were used as controls. Animals were fed with CRD ( $5 \%$ cholesterol) for 2 months. A control group of SHR $(n=10)$ received a standard pellet diet, 10 SHR were fed CRD and 10 SHR received CRD with daily administration of NSE per os at a dose of $50 \mathrm{mg} / \mathrm{kg}$ of body weight. The age of the rats at the beginning of the experiments was 6 months. The initial weight of rats was $195 \pm 15 \mathrm{~g}$, and the weight at the end of the experiments was $260 \pm 31 \mathrm{~g}$.

Animals were kept in standard cages with free access to food and water in accordance with General Ethical Principles of Experiments on Animals (Ukraine, 2001), which are consistent with the provisions of "The European Convention for the Protection of Vertebrate Animals Used for Experimental and Other Scientific Purposes" (Strasbourg, 1986). This study was carried out with the approval of the Animal Care and Use Committee of the Palladin Institute of Biochemistry, National Academy of Sciences of Ukraine (Protocol N1 from 08/09-2015).

After 2 months of experiments, animals were decapitated under Nembutal anesthesia (dosage was $50 \mathrm{mg} / \mathrm{kg}$ of body weight) according to the ethical standards and principles specified above. For further studies we collected samples of blood plasma and aorta tissues.

Detection of low- and high-density lipoprotein levels. Low density lipoproteins (LDL) and high density lipoproteins (HDL) were detected using commercial assay kits provided by Granum (Kharkiv, Ukraine). The assay is based on the inaccessibility of LDL to cholesterol oxidase and cholesterol esterase, whereas HDL reacts with these enzymes. The released LDL reacts with the enzymes to produce $\mathrm{H}_{2} \mathrm{O}_{2}$ which is quantified by the Trinder reaction.

Activated partial prothrombin time. Activated partial thromboplastin time (APTT) was performed according to the following procedure. $0.1 \mathrm{ml}$ of blood plasma was mixed with an equal volume of APTT-reagent and incubated for $3 \mathrm{~min}$ at $37^{\circ} \mathrm{C}$. 
Then the coagulation was initiated by adding $0.1 \mathrm{ml}$ of $0.025 \mathrm{M}$ solution of $\mathrm{CaCl}_{2}$. Clotting time was monitored by the Coagulometer Solar CGL-2410 (Solar, Minsk, Belorussia).

Fibrinogen concentration. Fibrinogen concentration in blood plasma was determined by the modified spectrophotometric method. Blood plasma $(0.2 \mathrm{ml})$ and PBS $(1.7 \mathrm{ml})$ were mixed in glass tubes. Coagulation was initiated by the addition of $0.1 \mathrm{ml}$ of thrombin-like enzyme from the venom of Agkistrodonhalyshalys $(0.5 \mathrm{NIH} / \mathrm{ml})$. The mixture was incubated for $30 \mathrm{~min}$ at $37{ }^{\circ} \mathrm{C}$. The fibrin clot was removed and redissolved in $5 \mathrm{ml}$ of $1.5 \%$ acetic acid. The concentration of protein was measured using the spectrophotometer Optizen POP (Mecacys, Seongnam, South Korea) at $280 \mathrm{~nm}(\varepsilon=1.5)$.

Protein $C$ level. The PC level was determined using the activator of PC from Agkistrodonhalyshalysvenom, as previously described [16]. The generation of activated PC was measured by chromogenic substrate assay using specific chromogenic substrate S2236 (p-Glu-Pro-Arg-pNa). The analysis was done in $0.05 \mathrm{M}$ Tris- $\mathrm{HCl}$ buffer $\mathrm{pH} 7.4$, at $37^{\circ} \mathrm{C}$. Chromogenic substrate concentration was $30 \mathrm{mM}$. A 96-well reader was used for the detection of optical density of released para-nitroaniline (ThermoFisher Scientific, San Francisco, USA).

Platelet aggregation. Platelet aggregation measurements were based on changes in the turbidity of human PRP [17 ]. Aggregation was registered for 10 min using the Aggregometer Solar AP2110 (Minsk, Belorussia). Platelet count was estimated using the same device. We measured the initial rate and final level of aggregation at $37^{\circ} \mathrm{C}$. In a typical experiment, $250 \mu \mathrm{l}$ of PRP was incubated with $\mathrm{CaCl}_{2}$ $(10 \mu \mathrm{M})$ activated by platelet agonist $\operatorname{ADP}(12.5 \mu \mathrm{M})$ at $37^{\circ} \mathrm{C}$.

Histology and aortic wall thickness measurement. Histological samples of the aorta for light-microscopic examination were prepared as previously described [18]. After decapitation, the fragment of the aorta was isolated and fixed in $10 \%$ neutral formalin for $24 \mathrm{~h}$. Then it was dehydrated in ethanol of increasing concentrations (70\%, 80\%, 90\%, 96\%) and the aortic fragment was embedded in paraffin. Sections of tissues $5 \mu \mathrm{m}$ thick were made on a microtome. The samples were stained by hematoxylin and eosin according to Ehrlich and studied by microscopy. Stained histological samples were studied using an Olympus BX51 microscope (Olympus, Tokyo, Japan).
Aortic wall thickness was measured using morphometric program Image $\mathrm{J}$ (National Institutes of Health, Bethesda, Maryland, USA).

Statistical analysis. Statistical data analysis was performed using the Mann-Whitney U test for independent groups in Microsoft Excel (Microsoft,Redmond, WA, USA). All assays were replicated thrice. Results are presented as means \pm standard deviation. A value was considered significant at $P<0.05$.

\section{Results}

Model development. Hypertension induce shear stress of endothelium and increases the risk of injury of vessels, especially in the case of dyslipidemia [19]. That is why a cholesterol diet that is insufficient for the development of atherosclerosis in healthy rats causes atherogenesis in SHR [9, 10].

To verify the adequacy of the atherosclerosis model, we examined: a) concentrations of high- and low-density lipoproteins as the indication of lipid balance disturbance; b) clotting time in the APTT test as the overall measure of procoagulant potential of the blood coagulation system [20]; and c) the morphology of the aorta for direct detection of atherosclerotic changes. According to recent knowledge, atherosclerosis consists of fats, cholesterol, calcium and other substances deposited and built up on the inner wall of arteries [21].

Dietary cholesterol overload caused a disturbance of the lipoprotein profile of rat blood plasma. An increase of almost 2 times in the content of plasma LDL and a 15\% increase of HDL compared to the control group was observed (Fig. 1). Such an imbalance between LDL and HDL is assumed to be direct evidence of atherosclerosis development [22].

Among obvious marks of atherosclerosis are intimal sickening, depositions of lipids and re-arrangement of vessel architecture [23]. In most of the studied animals we observed these changes. Small particles of lipids or edema zones that were not stained by hematoxylin and eosin (according to Ehrlich) were detected. Disrupted endothelium was detached in some cases, incorporation of lipids near its surface resembled classical atherosclerotic plaques (Fig. 2, A).

Direct comparison of aortic walls of control Wistar rats and SHR on standard diet did not show any significant difference in the thickness of the aorta or accumulation of lipids in the aortic media (Fig. 3, A). Quantitative analysis using ImageJ 
$A$

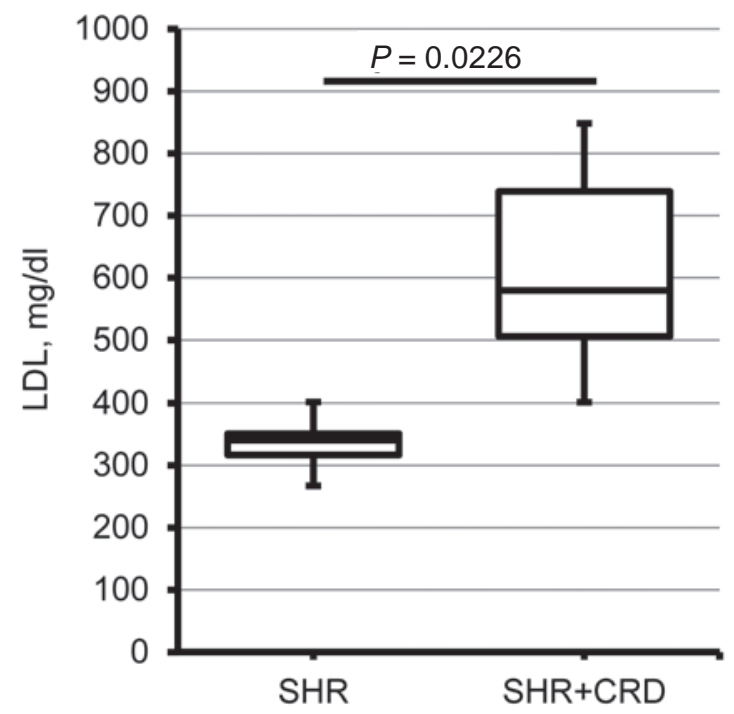

B

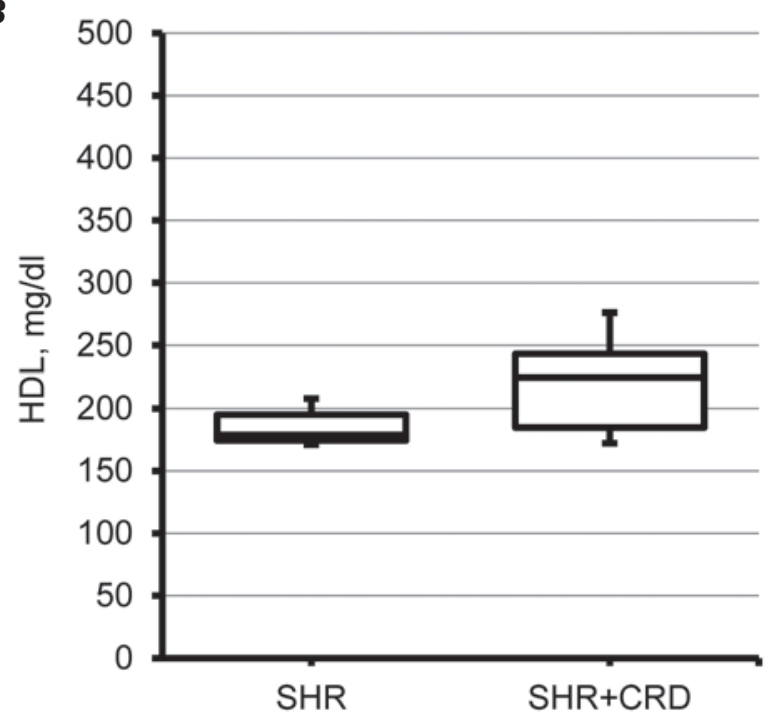

Fig. 1. The influence of cholesterol-rich diet (CRD) on levels of (A) low-density lipoproteins (LDL) and (B) high-density lipoproteins (HDL) in blood plasma of spontaneously hypertensive rats (SHR), fed CRD for 2 months. For $L D L$, the result is significantly different or $S H R+C R D$ vs $S H R(P=0.0226)$

software did not show any significant difference between these two groups (Fig. 2, D). Sporadic zones of edema or injured endothelium were found in SHR rats on standard diet but the changes were not systemic as in the case of SHR fed CRD. In particular, thickening of the aorta was observed in the group of SHR that was given CRD, and in these SHR+CRD animals the aortic wall was significantly increased in comparison to control Wistar rats $(P=0.0045)$ and to HSR on standard diet $(P=0.0023)$ (Fig. $2, B)$.

As for the APTT, this is a basic test that can indicate the pro-coagulant imbalance in the blood coagulation system. Shortening of APTT can indicate the increased risk of intravascular blood coagulation $[24,25]$. A significantly shortened APTT was observed for SHR+CRD vs SHR $(P=0.00262)$ (Fig. 2 , C).

Together with the imbalance in lipid metabolism and vessel wall disturbance, the shortening of blood clotting time in the APTT test confirmed the adequacy of the selected rat model. The next step was to study the effect of the anti-inflammatory action of NSE on atherogenesis.

NSE effect on the development of atherosclerosis in SHR fed CRD. NSE as an endogenously produced fatty acid compound was shown to possess anti-inflammatory action. In this study we measured the specific parameters that indicated both increased blood coagulation potential and the propagation of inflammatory responses: fibrinogen concentration and PC.

Fibrinogen is the acute phase protein whose concentration increases during inflammation. Also, fibrinogen synthesis is increased under the action of interleukin-6 [26, 27]. In our studies, animals treated with CRD showed elevated fibrinogen levels that completely corresponded to those reported in the literature.

Application of NSE slightly normalized the fibrinogen level, which confirms its anti-inflammatory effect (Fig. 3, A). However, NSE did not normalize the clotting time in the APTT test ( $30 \pm 3$ vs $23 \pm 3$ in atherosclerotic animals and $46 \pm 4 \mathrm{~s}$ in controls). Thus, this anti-inflammatory action did not provide an effective anti-thrombotic action.

Another blood coagulation system factor that changed during inflammation is PC. Being the crucial protein of the anticoagulant system, this proenzyme is activated and used to compensate the thrombin generation, and it also possesses antiinflammatory action. That is why a decreased PC concentration indicates not only activation of blood coagulation, but also the inflammatory processes. It is not surprising then that development of atherosclerosis led to a dramatic decrease of the PC level (by $30 \%$ in comparison to the control value). Also, application of the anti-inflammatory agentNSE significantly normalized the level of PC (Fig. 3, B). 
$A$

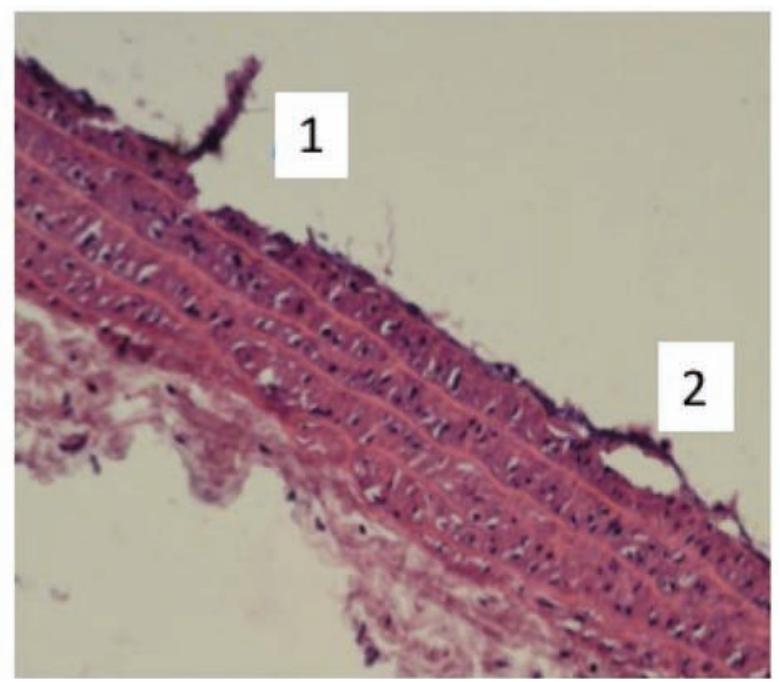

C

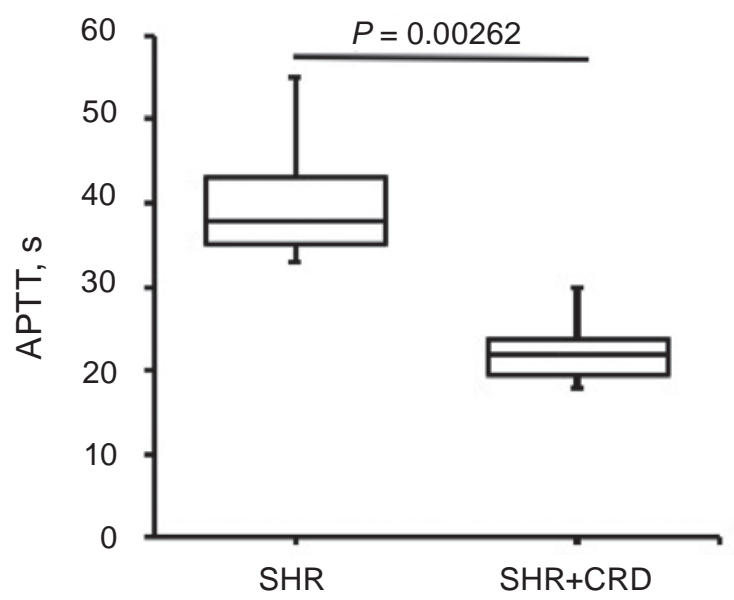

$B$

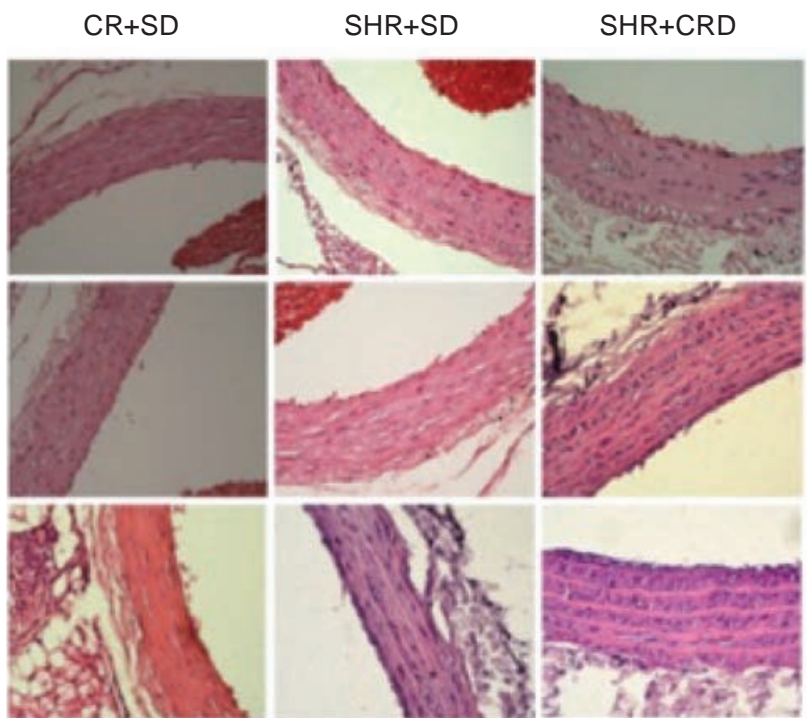

D

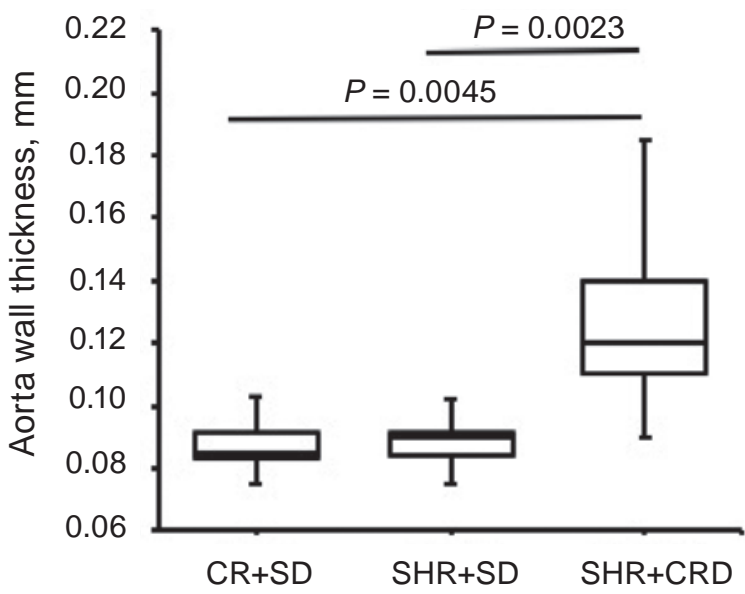

Fig. 2. (A) A typical sample of the aortic wall of spontaneously hypertensive rats (SHR) treated with cholesterol-rich diet (CRD). (1) Ruptured plaque, plaque and lipid incorporations are shown. (2) Atherosclerotic plaque. "Empty" space is covered by endothelial and smooth muscle cells. Recruited white cells are seen. (B) Representative sections of the aorta of individual control rats (Wistar) on standard diet (CR+SD), spontaneously hypertensive rats (SHR) on standard diet (SHR+SD) and SHR treated for 2 months with cholesterol-rich diet $(S H R+C R D)$. (C) The influence of cholesterol-rich diet (CRD) on the clotting time of blood plasma of spontaneously hypertensive rats (SHR), fed CRD for 2 months. APTT-activated partial thromboplastin time. The result is significantly different for SHR $+C R D$ vs SHR $(P=0.00262)$. (D) Thickness of the aortic wall of $C R+S D$, SHR $+S D$ andSHR+CRD calculated using ImageJ software. The results are significantly different for $S H R+C R D$ vs $S H R+S D(P=0.0023)$ and for $S H R+C R D$ vs $C R+S D(P=0.0045)$

The cellular branch of haemostasis is the most sensitive to inflammation processes so the change of platelet reactivity is evidence of an inflammatory response. Both chronic inflammation and the development of atherosclerosis cause increases in the level and rate of platelet aggregation [28].

Our results showed that atherosclerosis development in the studied model led to increased platelet reactivity. The level of platelet aggregation in blood plasma of atherosclerotic animals in most cases increased greatly, reaching 60\%. The aggregation curves for blood plasma from rats given NSE were much lower (Fig. 4).

The speed of platelet aggregation was greatly affected by CRD. We determined that the speed of platelet aggregation in PRP of atherosclerotic ani- 
$A$

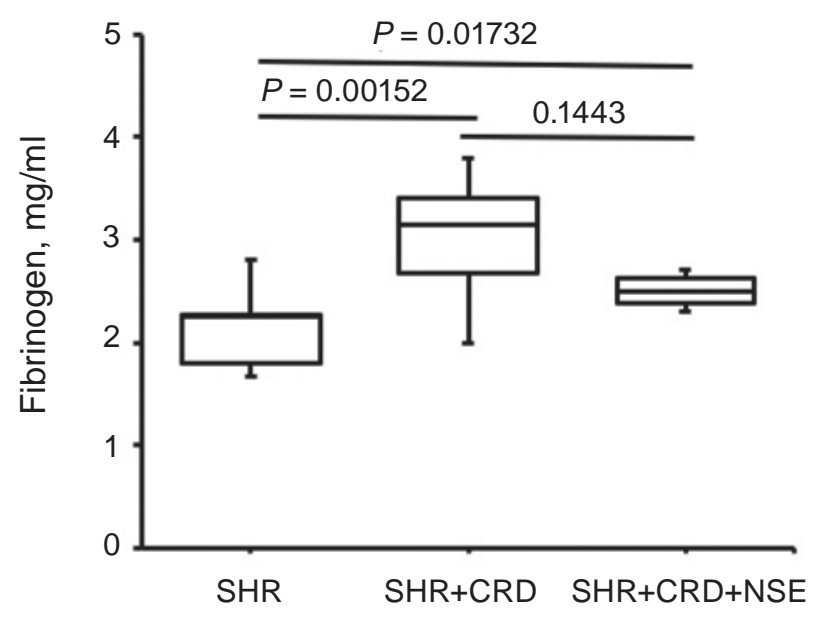

B

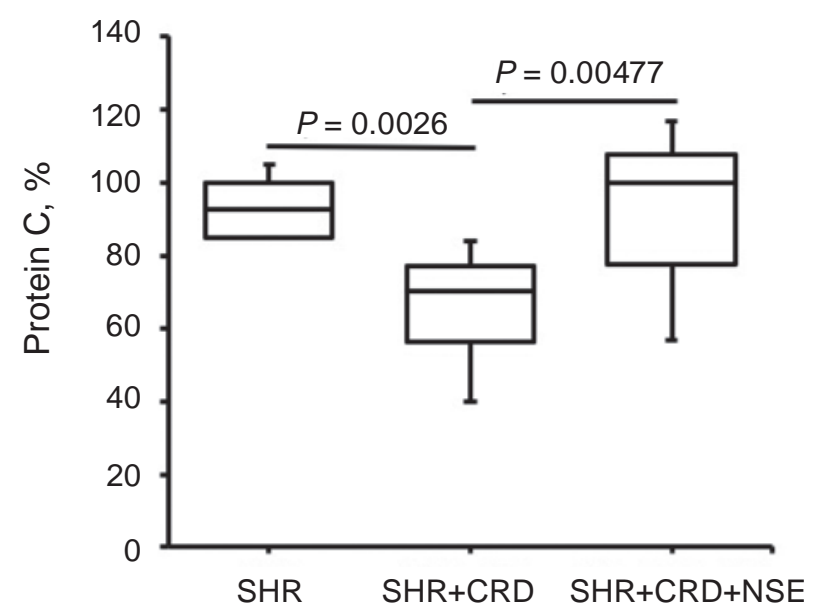

Fig. 3. (A) The influence of $N$-stearoylethanolamine (NSE) on the fibrinogen levelin blood plasma of spontaneously hypertensive rats (SHR), fed cholesterol-rich diet (CRD) for 2 months. $S H R+C R D+N S E-S H R$ fed CRD and given $50 \mathrm{mg} / \mathrm{kg}$ of NSE daily per os. The results are significantly different for SHR+CRD+NSE vs SHR $(P=0.01732)$ and for $S H R+C R D$ vs $S H R(P=0.00152)$. (B) The influence of $N$-stearoylethanolamine (NSE) on protein $C$ in the blood plasma of spontaneously hypertensive rats (SHR), fed cholesterol-rich diet (CRD) for 2 months. SHR+CRD $+N S E-S H R$ fed CRD and given $50 \mathrm{mg} / \mathrm{kg}$ of NSE daily per os. The results are significantly different for $S H R+C R D+N S E$ vs $S H R+C R D(P=0.0477)$ and for $S H R+C R D$ vs $S H R(P=0.0026)$
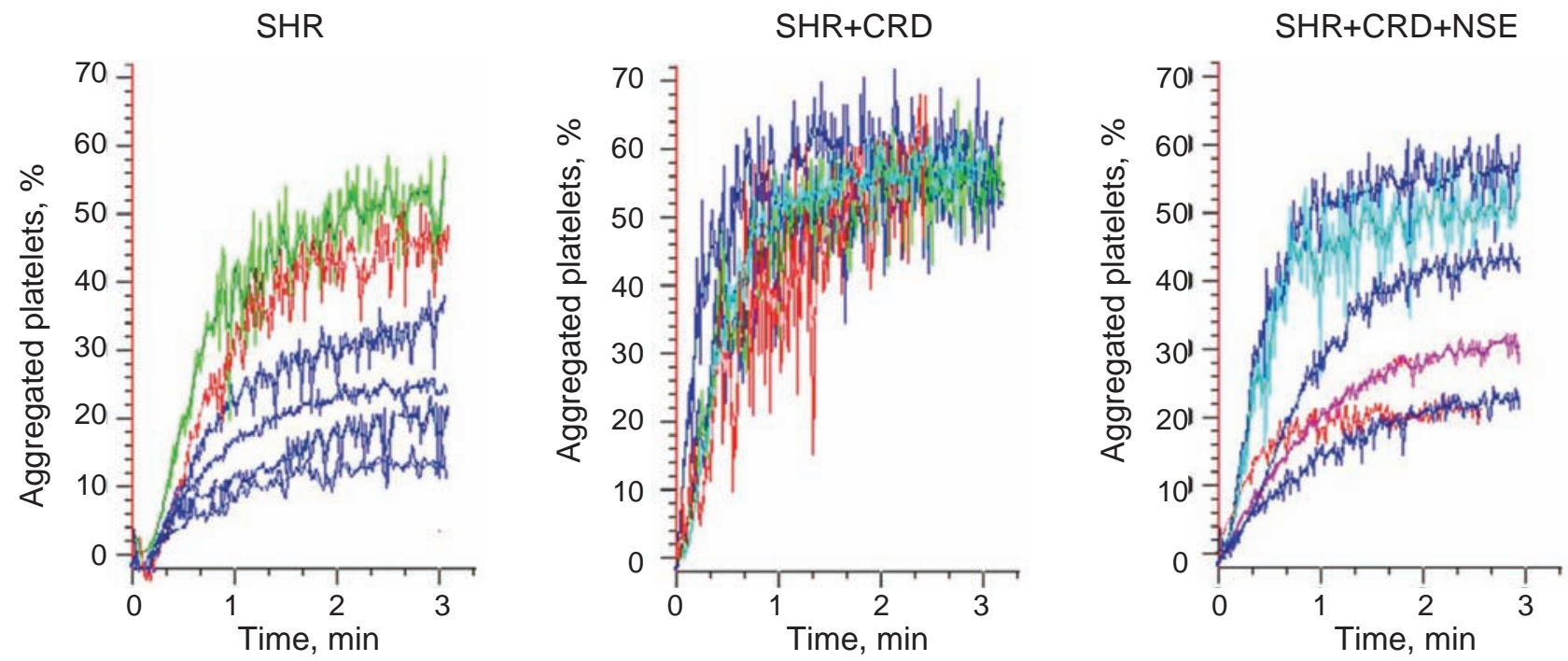

Fig. 4. The individual curves of platelet aggregation in blood plasma of individual spontaneously hypertensive rats (SHR) cholesterol-rich diet (CRD) for 2 months $(S H R+C R D)$ and the effect of $N$-stearoylethanolamine (NSE) on this parameter. SHR+CRD+NSE SHR fed CRD and given $50 \mathrm{mg} / \mathrm{kg}$ of NSE daily per os

mals was $50 \pm 10 \% / \mathrm{min}$ vs $20 \pm 14 \% / \mathrm{min}$ in control SHRon standard diet. The application of NSE decreased this value to $25 \pm 10 \% / \mathrm{min}$. The individual curves in Fig. 5 show that platelet parameters varied in different rats within each group and that CRD promoted platelet reactivity in all studied rats.
Thus, we observed that the anti-inflammatory action of NSE fully restored PC level and partially normalized the concentration of fibrinogen and reactivity of platelets which are greatly affected during atherosclerosis. The next step was to detect the pos- 
SHR
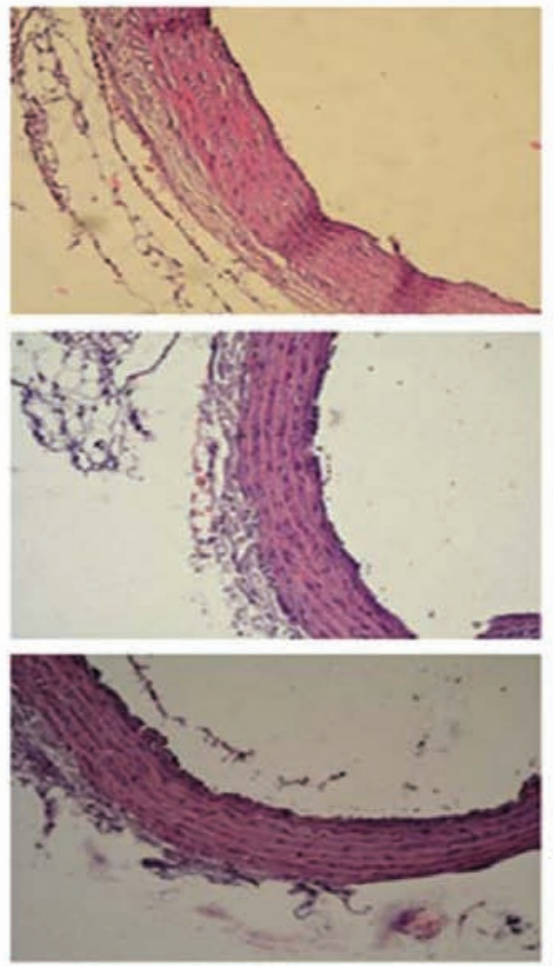

SHR+CRD
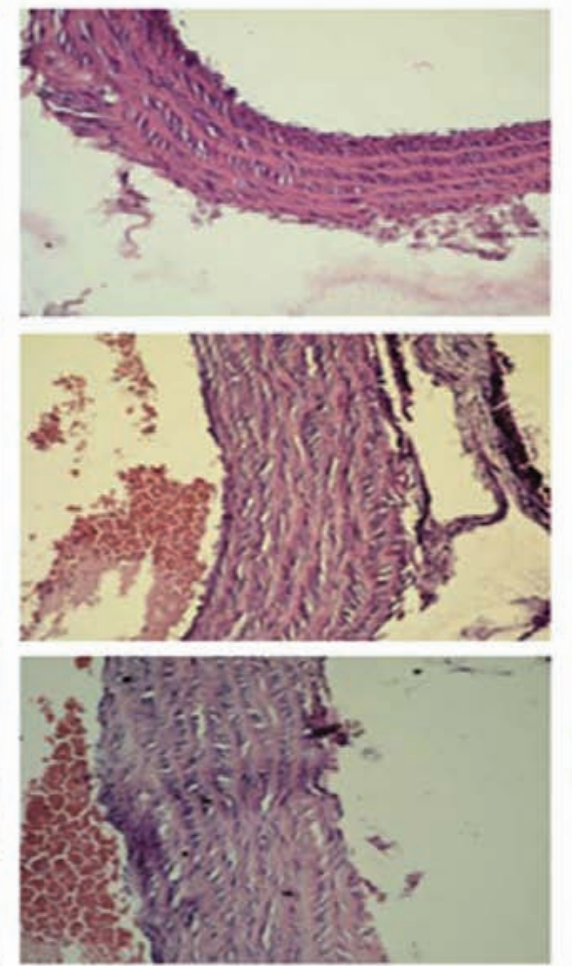

SHR+CRD+NSE
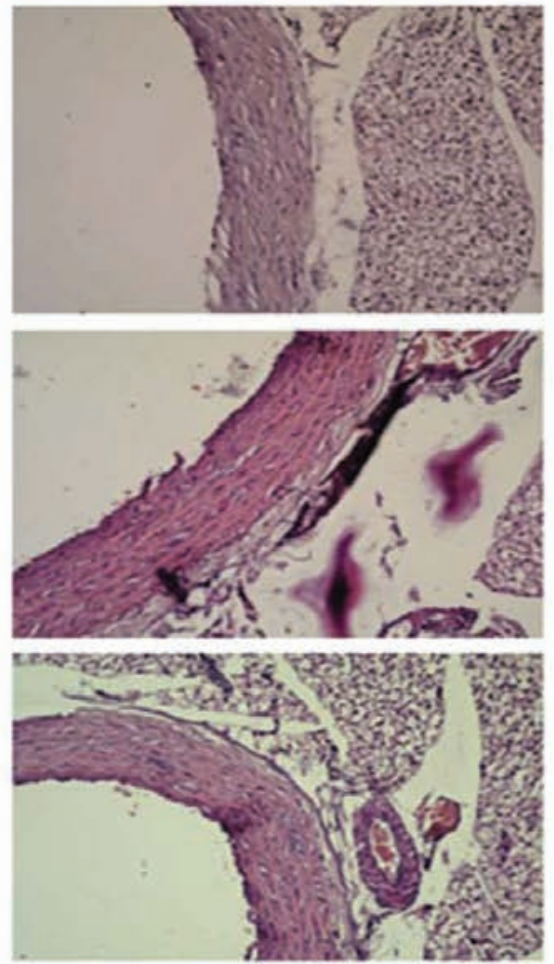

Fig. 5. Representative sections of the aorta of individual spontaneously hypertensive rats (SHR) fed cholesterol-rich diet (CRD) for 2 months (SHR+CRD)and the effect of NSE on the aortic wall architecture. $S H R+C R D+N S E S H R$ fed CRD and given $50 \mathrm{mg} / \mathrm{kg}$ of NSE daily per os

sible effects of NSE on the aortic wall of atherosclerotic rats.

Histological analysis of the aortic wall of rats showed that the administration of NSE during the development of the atherosclerosis model affects the architecture of the aortic wall (Fig. 5). In particular, the majority of the studied samples showed a visible aortic thinning compared to the self-rehabilitation group. The thickness of the aortic wall of rats treated with NSE was close to the control values. At the same time however, in the media of the aortic wall of rats receiving NSE altered tissue was observed. It appears as a white area that is not stained, and therefore contains elements of connective tissue or lipids, covered with a thin layer of endothelium (Fig. 5).

ImageJ analysis of the images allowed us to obtain quantitative data. Despite the clear tendency toward thinning, the aortic wall of rats with induced atherosclerosis receiving NSE is still thicker than the aortic wall of control rats (Fig. 6, A) (with a reliability of $P<0.1$ ).

We also calculated the percentage of altered tissue in the aortic media. The calculations of the total area of white inclusions using ImageJ software showed that the use of NSE did not reduce the amount of degenerated tissue in the aortic media (Fig. 6, B).

\section{Discussion}

Thus the use of CRD in SHR allowed us to obtain a model of atherosclerosis, which demonstrated reliable thickening and edema of the aorta of the rats, disorders of aorta intimae and formation of atherosclerotic plaques on its surface. It was shown that the development of atherosclerosis in rats is accompanied by a sharp decrease in PC content, an increase in fibrinogen concentration and promotion of platelet reactivity, an acceleration of blood plasma procoagulant potential.

Taking into account the valuable contribution of the blood coagulation system to the development of atherosclerosis shown by Hugo ten Cate et al. [11, 12], we assumed that the hyper-coagulability of the studied rats is an important marker of atherogenesis. Moreover, pathological activation of the blood coagulation system is closely related to atheroscle- 
$A$

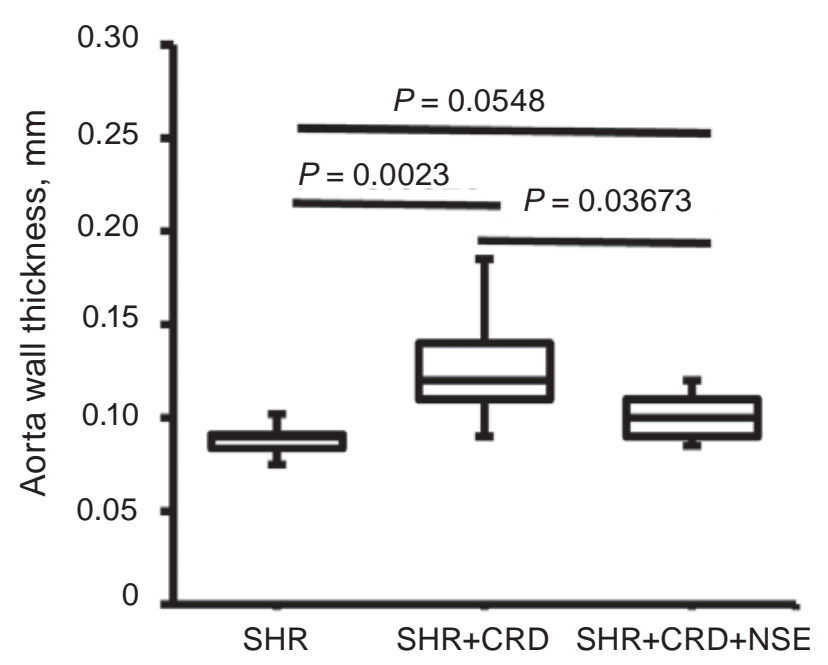

B

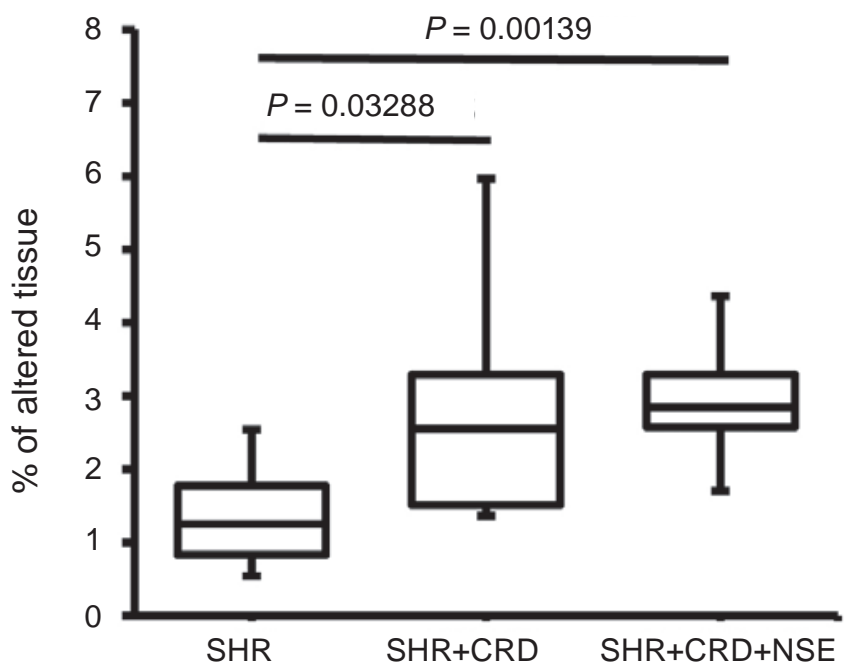

Fig. 6. (A) Aortic wall thickness and (B) percentage of adipose and connective tissue inclusions in the aortic wall of spontaneously hypertensive rats (SHR) treated with cholesterol-rich diet (CRD) for 2 months (SHR+CRD) and the effect of NSE on the aortic wall architecture calculated using ImageJ software. SHR+CRD+NSESHR fed CRD and given $50 \mathrm{mg} / \mathrm{kg}$ of NSE daily per os. Results are significant for $P<0.05$

rosis, sometimes resulting in the most dangerous manifestation of the latter atherothrombosis. It is not surprising then, that application of anticoagulant medications prevents not only intravascular clot formation but also the atherosclerotic changes in the walls of the vessels [29].

In this study we applied another strategy of treatment for atherosclerosis. Instead of inhibiting blood coagulation, we used an anti-inflammatory agent. No one could predict that the endogenously produced fatty acid compound NSE can inhibit blood coagulation, omitting its moderate anti-aggregatory effect on platelets [30]. However its anti-inflammatory effects are well known and widely studied. Among various anti-inflammatory effects shown for NSE in vivo, its per oral application decreases the level of cytokine TNF-alpha [31, 32].

\section{Conclusion}

According to the results, we observed a normalization of those blood coagulation parameters that mostly depend on the inflammatory response, in particular the PC level and platelet aggregation. We also observed some effects on the thickness of the aorta and removaling of edema under the action of NSE. We can conclude that the use of NSE during the production of atherosclerosis in rats did not allow normalization of the procoagulant potential of the blood plasma of experimental rats, but helped to reduce the manifestations of inflammation that accompany atherogenesis. Thus, NSE cannot be assumed as a antithrombotic or antiatherogenic agent, being unable to influence hemostasis directly, but we can speculate about the possibility of NSE administration as an additional agent to increase the efficacy of anticoagulant therapy.

Conflict of interest. Authors have completed the Unified Conflicts of Interest form at http://ukrbiochemjournal.org/wp-content/uploads/2018/12/coi_ disclosure.pdf and declare no conflict of interest.

Acknowledgement. We thank Cedars - Sinai Medical Center International Research and Innovation in Medicine Program, the Association for Regional Cooperation in the Fields of Health, Science and Technology (RECOOP HST Association) for their support of our organization asa participating Cedars - Sinai Medical Center - RECOOP Research Center (CRRC). This article contains the results of studies conducted by the President of Ukraine scholarship for young scientists awardee Oksana Tkachenko (2018-2020). 


\section{ПРОТЕКТОРНИЙ ЕФЕКТ N-СТЕАРОЇЛЕТАНОЛАМІНУ НА СИСТЕМУ ЗГОРТАННЯ КРОВІ ТА АРТЕРІАЛЬНІ ЗМІНИ У СПОНТАННО ГІПЕРТОНІЧНИХ ЩУРІВ ЗА УМОВ ДІЕТИ БАГАТОЇ ХОЛЕСТЕРОЛОМ}

О. С. Ткаченко, С. А. Гудзи ${ }^{1 凶,}$ Г. В. Косякова 1 , П. П. Клименко ${ }^{2}$, Є. М. Стогній T. М. Чернишенко ${ }^{1}$ В. О. Чернишенко ${ }^{1}$, T. М. Платонова ${ }^{1}$

${ }^{1}$ Інститут біохімії імені Палладіна НАН України, Київ;

${ }^{2} Д У$ «Іінститут геронтології ім. Д. Ф. Чеботарьова НАМН України», Київ;

凶e-mail: goudziegor@gmail.com

У цій роботі ми мали на меті перевірити атеросклеротичні зміни стінки аорти та прокоагулянтну реакцію системи згортання крові у спонтанно гіпертонічних щурів (СГЩ), що отримували дієту 3 високиим вмістом холестеролу (ДВХ), та вивчити антизапальну дію $\mathrm{N}$-стеароілетаноламіну (NSE) на розвиток атеросклерозу в цій моделі. Самиці щурів $(n=30)$ 3 генетичною схильністю до гіпертензії, верифіковані вимірюванням артеріального тиску, отримували дієту з високим вмістом холестеролу (5\%) протягом 2 місяців. Тварини були поділені на три групи: 1 - контрольна група СГЩ отримувала стандартний раціон віварію; 2 група отрумувала ДВХ; 3 група отримувала ДВХ + NSE в дозі 50 мг/кг. Гістологічний аналіз виявив набряк та відшарування ендотеліальних клітин, набряк субендотеліального шару та порушення цілісності середньої оболонки. Щури які отримували дієту з високим вмістом холетеролу мали більш високу концентрацію фібриногену, збільшену швидкість агрегації тромбоцитів i зниження рівня протеїну С. Швидкість агрегації тромбоцитів збільшувалась у щурів, які отримували ДВХ (52,5 $\pm 4,1 \% /$ хв), незначно нормалізувалася під дією NSE (40 \pm 8,3 проти $35 \pm 9 \% /$ хв у контрольних групах). Концентрація фібриногену трохи збільшувалась у щурів, які отримували ДВХ $(2,75 \pm 0,7$ проти $1,9 \pm 0,5$ мг/ мл у контрольних групах). Однак рівень антикоагулянтного протеїну $\mathrm{C}$, який знизився у щурів, що отримували ДВХ $(65 \pm 16$ проти $100 \pm 11 \%$ у контролях), нормалізувався під дією NSE (92 \pm 17\%). NSE також впливав на архітектуру аорти, однак нормалізація товщини стінки аорти не змінила кількості включень холестерину у її стінці. Показано, що протизапальна дія NSE змінює атерогенні процеси щурів, які отримували ДВХ, головним чином нормалізуючи рівень протеїну $\mathrm{C}$ під час запального процесу та зменшуючи набряк аорти. Однак гематологічні параметри (включно 3 часом згортання в тесті АРТТ та концентрацією фібриногену) змінювались незалежно під час застосування NSE. Антиагрегантна дія NSE на тромбоцити може бути наслідком прямої дії на тромбоцити або наслідком його протизапальної дії. Під час атерогенезу, індукованого ДВХ у моделі, NSE продемонстрував цінні протизапальні дії, що захищають організм під час атерогенезу, однак його не можна вважати антитромботичним чи антиатерогенним агентом, оскільки він нездатний впливати на гемостаз безпосередньо.

К л юч в в с лов а: атеросклеро3, дієта 3 високим вмістом холестеролу, $\mathrm{N}$-стеароїлетаноламін (NSE), гемостаз.

\section{References}

1. Libby P, Buring JE, Badimon L, Hansson GK, Deanfield J, Bittencourt MS, Tokgözoğlu L, Lewis EF. Atherosclerosis. Nat Rev Dis Primers. 2019; 5(1): 56.

2. Rafieian-Kopaei M, Setorki M, Doudi M, Baradaran A, Nasri H. Atherosclerosis: Process, Indicators, Risk Factors and New Hopes. Int $J$ Prev Med. 2014; 5(8): 927-946.

3. von Scheidt M, Zhao Y, Kurt Z, Pan C, Zeng L, Yang X, Schunkert H, Lusis AJ. Applications and Limitations of Mouse Models for Understanding Human Atherosclerosis. Cell Metab. 2017; 25(2): 248-261.

4. Dornas WC, de Oliveira TT, Augusto LEF, Nagem TJ. Experimental atherosclerosis in rabbits. Arq Bras Cardiol. 2010; 95(2): 272-278.

5. Emini Veseli B, Perrotta P, De Meyer GRA, Roth L, Van der Donckt C, Martinet W, De Meyer GRY. Animal models of atherosclerosis. Eur J Pharmacol. 2017; 816: 3-13.

6. Yamori Y. Rat Models for Atherosclerosis. In: Goldbourt U., de Faire U., Berg K. (eds) Genetic factors in coronary heart disease. Dev Cardiovasc Med. 1994; 156: 179-187. 
7. Pisulewski PM, Franczyk M, Kostogrys RB, Lorkowska B, Bartuś B, Chłopicki S. Spontaneously hypertensive rats are resistant to hypercholesterolaemia-induced atherosclerosis. J Anim Feed Sci. 2006; 15(1): 103-114.

8. Cappelli-Bigazzi M, Rubattu S, Battaglia C, Russo R, Enea I, Ambrosio G, Chiariello M, Volpe M. Effects of high-cholesterol and atherogenic diets on vascular relaxation in spontaneously hypertensive rats. Am J Physiol. 1997; 273(2 Pt 2): H647-H654.

9. Tumanovska LV, Swanson RJ, Serebrovska ZO, Portnichenko GV, Goncharov SV, Kysilov BA, Moibenko OO, Dosenko VE. Cholesterol enriched diet suppresses ATF6 and PERK and upregulates the IRE1 pathways of the unfolded protein response in spontaneously hypertensive rats: Relevance to pathophysiology of atherosclerosis in the setting of hypertension. Pathophysiology. 2019; 26(3-4): 219-226.

10. Pashevin DO, Honcharov SV, Tumanovs'ka LV, Dosenko VIe, Moibenko OO. The changes in the activity of tripeptidyl peptidase II in experimental atherosclerosis and hypertension. Fiziol Zh. 2014; 60(3): 27-31. (In Ukrainian).

11. Maeda M, Tsuboi T, Hayashi T. An inhibitor of activated blood coagulation factor $\mathrm{X}$ shows antiendothelial senescence and anti-atherosclerotic effects. J Vasc Res. 2019; 56(4): 181-190.

12. Posthuma JJ, Posma, JJN, van Oerle R, Leenders P, van Gorp RH, Jaminon AMG, Mackman N, Heitmeier S, Schurgers LJ, ten Cate H, Spronk HMH. Targeting coagulation factor Xa promotes regression of advanced atherosclerosis in apolipoprotein-E deficient mice. Sci Rep. 2019; 9(1): 3909.

13. Goridko TM, Gula NM, Margitich VM, Govseyeva NM, Klimashevsky VM, Shagidulin MYu. Influence of N-palmitoylethanolamine on phospholipid and fatty acid content in the rat liver under ischemia. Ukr Biokhim Zhurn. 2001; 73(1): 82-87. (In Ukrainian).

14. Gula NM, Margitich VM, Klimashevsky VM, Goridko TM, Artamonov MV, Zhukov OD. Neuroprotective effect of $\mathrm{N}$-acylethanolamines under chronic morphine dependenc. II. Effect on rat brain fatty acid composition. Ukr Biokhim Zhurn. 2005; 77(2): 112-117. (In Ukrainian).

15. Goridko TM, Gula NM, Stogniy NA, Meged OF, Klimashevsky VM, Shovkun SA,
Kindruk NL, Berdyshev AH. Influence of $\mathrm{N}$-stearoylethanolamine on the lipid peroxidation process and lipid composition of the rat liver under acute morphine intoxication. Ukr Biokhim Zhurn. 2007; 79(5): 175-185. (In Ukrainian).

16. Gornitskaia OV, Platonova TN. Isolation and properties of the protein $\mathrm{C}$ activator from Agkistrodon halys halys venom. Biomed Khim. 2003; 49(5): 470-478. (In Russian).

17. Cattaneo $M$, Cerletti C, Harrison $P$, Hayward CPM, Kenny D, Nugent D, Nurden P, Rao AK, Schmaier AH, Watson SP, Lussana F, Pugliano MT, Michelson AD. Recommendations for the Standardization of Light Transmission Aggregometry: A Consensus of the Working Party from the Platelet Physiology Subcommittee of SSC/ISTH. J Thromb Haemost. 2013; 11(6): 1183-1189.

18. Tulis DA. Histological and morphometric analyses for rat carotid artery balloon injury model. Methods Mol Med. 2007; 139: 31-66.

19. Dzau VJ. Atherosclerosis and hypertension: mechanisms and interrelationships. J Cardiovasc Pharmacol. 1990; 15(Suppl 5): S59-S64.

20. Loeffen R, Spronk HMH, ten Cate H. The impact of blood coagulability on atherosclerosis and cardiovascular disease. J Thromb Haemost. 2012; 10(7): 1207-1216.

21. Noyd RK, Krueger JA, Hill KM. Biology: Organisms and Adaptations. Cengage Learning. 2016. $731 \mathrm{p}$.

22. Hao W, Friedman A. The LDL-HDL Profile determines the risk of atherosclerosis: a mathematical model. PLoS ONE. 2014; 9(3): e90497.

23. Nakashima Y, Wight TN, Sueishi K. Early atherosclerosis in humans: role of diffuse intimal thickening and extracellular matrix proteoglycans. Cardiovasc Res. 2008; 79(1): 1423.

24. Lippi G, Salvagno GL, Ippolito L, Franchini M, Favaloro EJ. Shortened activated partial thromboplastin time: causes and management. Blood Coagul Fibrinolysis. 2010; 21(5): 459-463.

25. Tripodi A, Chantarangkul V, Martinelli I, Bucciarelli P, Mannucci PM. A shortened activatedpartialthromboplastintimeis associated with the risk of venous thromboembolism. Blood. 2004; 104(12): 3631-3634.

26. Coronado S, Zakzuk J, Regino R, Ahumada V, Benedetti I, Angelina A, Palomares O, 
Caraballo L. Ascaris lumbricoides Cystatin Prevents Development of Allergic Airway Inflammation in a Mouse Model. Front Immunol. 2019; 10: 2280.

27. Stoppa-Vaucher S, Dirlewanger MA, Meier CA, de Moerloose P, Reber G, Roux-Lombard P, Combescure C, Saudan S, Schwitzgebel VM. Inflammatory and prothrombotic states in obese children of European descent. Obesity (Silver Spring). 2012; 20(8): 1662-1668.

28. Nording HM, Seizer P, Langer HF. Platelets in inflammation and atherogenesis. Front Immunol. 2015; 6: 98.

29. Olie RH, van der Meijden PEJ, Ten Cate H. The coagulation system in atherothrombosis: Implications for new therapeutic strategies. Res Pract Thromb Haemost. 2018; 2(2): 188-198.

30. Dziuba OS, Chernyshenko VO, Hudz IeA, Kasatkina LO, Chernyshenko TM, Klymenko PP, Kosiakova HV, Platonova TM,
Hula NM, Lugovskoy EV. Blood coagulation and aortic wall integrity in rats with obesityinduced insulin resistance. $U$ kr Biochem J. 2018; 90(2): 14-23.

31. Zhukov OD, Berdyshev AH, Kosiakova HV, Klimashevskiy VM, Gorid'ko TM, Meged OF, Hula NM. N-stearoylethanolamine effect on the level of 11-hydroxycorticosteroids, cytokines IL1, IL-6 and TNFalpha in rats with nonspecific inflammation caused by thermal burn of skin. Ukr Biochem J. 2014; 86(3): 88-97. (In Ukrainian).

32. Berdyshev AG, Kosiakova HV, Onopchenko OV, Panchuk RR, Stoika RS, Hula NM. $\mathrm{N}$-Stearoylethanolamine suppresses the proinflammatory cytokines production by inhibition of NF- $\mathrm{kB}$ translocation. Prostaglandins Other Lipid Mediat. 2015; 121(Pt A): 91-96. 